\title{
CULTURE SHOCK DAN INTERAKSI SOSIAL MAHASISWA PROGRAM STUDI S1 ILMU KEPERAWATAN UNIVERSITAS RESPATI YOGYAKARTA
}

\author{
DIFRAN NOBEL BISTARA \\ UNIVERSITAS RESPATI YOGYAKARTA \\ difran89@gmail.com
}

\begin{abstract}
ABSTRAK
Pendidikan adalah salah satu alasan mengapa beberapa orang bermigrasi dan bersedia pergi untuk mendapatkan pendidikan lebih tinggi dan memiliki kualitas baik. Pertemuan dengan akademisi dari berbagai budaya, terutama pada mahasiswa Universitas Respati Yogyakarta menjadi suatu bentuk interaksi sosial. Kegagalan untuk berinteraksi secara efektif dengan orang lain akan mengakibatkan gangguan interaksi sosial seseorang. Kesulitan dalam berinteraksi disebabkan oleh keanekaragaman budaya. Studi yang pernah dilakukan dalam ilmu keperawatan dari Universitas Gajah Mada ada 100\% mengalami culture shock. Penelitian ini menggunakan desain analitik korelasi dengan pendekatan cross-sectional. Sampel adalah mahasiswa baru diambil dengan teknik stratified sampling. Analisis data yang digunakan adalah rank spearman. Hasil uji statistik diperoleh $\mathrm{p}=0.075(\alpha<0.05)$ dan $\mathrm{r}=0348$ sehingga tidak ada hubungan culture shock dengan interaksi sosial pada mahasiswa ilmu keperawatan di Universitas Respati Yogyakarta. Mahasiswa diharapkan mampu beradaptasi dengan lingkungan untuk meningkatkan interaksi sosial.
\end{abstract}

Kata kunci: culture shock, interaksi sosial

\begin{abstract}
Education is one of the reasons why some people migrate and are willing to go to get a higher education and have a good quality. Meeting with academics from various cultures, particularly in Yogyakarta Respati University student into a form of social interaction. Failure to interact effectively with others will result in impaired social interaction a person. Difficulty in interacting caused by cultural diversity. The study ever conducted in nursing science from the University of Gajah Mada there 100\% experienced a culture shock. This study uses correlation analytic design with cross-sectional approach. Samples are taken with the new students stratified sampling technique. The data analysis used was Spearman rank. Statistical test results obtained $p=0.075(\alpha$ $<0,05)$ and $r=0348$ so that there is no relationship with the culture shock of social interaction in nursing science students at the University of Respati Yogyakarta. Students are expected to adapt to the environment to improve social interaction.
\end{abstract}

Keywords: culture shock, sosial interaction 


\section{PENDAHULUAN}

Indonesia memiliki berbagai suku bangsa, kebiasaan, bahasa, agama, adat istiadat dan cara hidup yang berbeda. Indonesia mempunyai bermacam-macam suku bangsa berikut budaya yang ada di Indonesia yang berjumlah 656 suku bangsa yang dapat teridentifikasi. ${ }^{1}$ Keberagaman ini menjadi tantangan tersendiri bagi masyarakat Indonesia memasuki era globalisasi. Pesatnya perkembangan teknologi, terutama di bidang transportasi menimbulkan peningkatan mobilitas dan migrasi penduduk yang semakin nyata, yang memungkinkan terjadi pertemuan lintas budaya. Pertemuan ini menimbulkan terjadinya interaksi yang lebih jauh antar budaya yang berbeda.

Manusia berinteraksi dengan sesamanya dalam kehidupan untuk menghasilkan pergaulan hidup dalam suatu kelompok sosial. Pergaulan hidup semacam itu baru akan terjadi apabila manusia dalam hal ini orang perorangan atau kelompokkelompok manusia bekerja sama, saling berbicara untuk mencapai tujuan bersama mengadakan persaingan, pertikaian, dan lain sebagainya. ${ }^{2}$ Sebagian mahasiswa yang berasal dari luar daerah beradaptasi terhadap budaya baru dengan adaptasi lintas budaya. Hambatan untuk berinteraksi sosial sering kali muncul, seperti dalam penggunaan bahasa, lambang-lambang, nilai atau norma-norma masyarakat. ${ }^{3}$ Syarat untuk terjadinya interaksi pada mahasiswa tingkat satu harus ada saling pengertian dan pertukaran informasi atau makna antara satu dengan lainnya.

Ketidakberhasilan untuk berinteraksi secara efektif dengan orang lain akan mengakibatkan gangguan interaksi sosial bagi orang tersebut ${ }^{4}$. Kesulitan dalam berinteraksi dialami seseorang jika depresi, kecemasan dan perasaan tidak berdaya menumpuk, derajat dan tingkat disorientasi psikologis buruk. ${ }^{5}$ Seseorang bepergian atau pindah ketatanan sosial dan budaya baru dapat mengalami kecemasan dan depresi yang merupakan manifestasi dari culture shock. Kesulitan dalam berinteraksi dialami seseorang disebabkan oleh culture shock. ${ }^{6}$

Program Studi S1 Ilmu Keperawatan UNRIYO memiliki mahasiswa dengan latar belakang dan budaya dari daerah asal yang cukup beragam. Keberagaman tersebut memungkinkan terjadinya pertemuan lintas budaya dan selanjutnya mengalami interaksi sosial dan dapat mengalami kesulitan dalam beradaptasi dengan teman sejawat yang berbeda kebudayaan. Berdasarkan latar belakang tersebut, peneliti ingin mengetahui hubungan culture shock dengan interaksi sosial pada mahasiswa tingkat satu yang berasal dari luar Yogyakarta.

\section{METODE}

Jenis penelitian yang digunakan adalah analitik korelasi dengan pendekatan cross sectional. Hal ini dilakukan untuk melihat hubungan antara culture shock dengan interaksi sosial pada Mahasiswa Tingkat Satu Angkatan 2010/2011 Program Studi S1 Ilmu Keperawatan Universitas Respati Yogyakarta. Penelitian ini dilaksanakan pada bulan 11-23 April 2011. Populasi dalam penelitian ini adalah 264mahasiswa tingkat satu angkatan 2010/2011 Program Studi S1 Ilmu Keperawatan Universitas Respati Yogyakarta yang berasal dari luar Yogyakarta. Sampel sebanyak 159 orang didapatkan dengan cara stratified sampling. Dalam penelitian ini yang menjadi variabel independen adalah culture shock. Variabel dependen adalah interaksi sosial pada mahasiswa tingkat satu. Instrumen yang digunakan dalam penelitian ini adalah kuesioner tentang culture shock dan interaksi sosial pada mahasiswa baru.

HASIL

Tabel 1 Karakteristik Responden

\begin{tabular}{|c|c|c|c|}
\hline No & $\begin{array}{c}\text { Karakteristik } \\
\text { Responden }\end{array}$ & Jumlah & Persentase \\
\hline \multirow[t]{4}{*}{1.} & Umur (Tahun) & & \\
\hline & 17 tahun & 8 & $5 \%$ \\
\hline & 18 tahun & 61 & $38.4 \%$ \\
\hline & $\geq 19$ tahun & 90 & $56.6 \%$ \\
\hline \multirow[t]{3}{*}{2.} & Jenis Kelamin & & \\
\hline & Laki-laki & 73 & $45.9 \%$ \\
\hline & Perempuan & 86 & $54.1 \%$ \\
\hline \multirow[t]{10}{*}{3.} & Asal Daerah & & \\
\hline & Sumatera & 15 & $9.4 \%$ \\
\hline & Jawa & 1 & $0.6 \%$ \\
\hline & Bali & 16 & $10.1 \%$ \\
\hline & Kalimantan & 29 & $18.2 \%$ \\
\hline & Nusa Tenggara & 79 & $49.7 \%$ \\
\hline & Maluku & 13 & $8.2 \%$ \\
\hline & Sulawesi & 1 & $0.6 \%$ \\
\hline & Papua & 5 & $3.1 \%$ \\
\hline & tal Responden & 159 & $100 \%$ \\
\hline
\end{tabular}

Sebagian besar responden berumur $\geq 19$ tahun yaitu 90 responden $(56.6 \%)$. Sebagian responden berjenis kelamin perempuan yaitu 
86 responden $(54.1 \%)$. Sebagian responden berasal dari Nusa Tenggara yaitu sebanyak 79 responden $(49.7 \%$.

Tabel 2 Frekuensi Culture Shock

\begin{tabular}{ccc}
\hline Kategori & Frekuensi & \% \\
\hline Culture Shock & 47 & 29.6 \\
\hline $\begin{array}{c}\text { Tidak Culture } \\
\text { Shock }\end{array}$ & 112 & 70.4 \\
\hline Total & 159 & 100 \\
\hline
\end{tabular}

Sebagian besar responden tidak mengalami culture shock yaitu sebanyak 112 responden $(70.4 \%)$.

Tabel 3 Interaksi Sosial Responden

\begin{tabular}{ccc}
\hline Kategori & Frekuensi & \% \\
\hline Baik & 18 & 11.3 \\
\hline Sedang & 137 & 86.2 \\
\hline Kurang & 4 & 2.5 \\
\hline Total & 159 & 100 \\
\hline
\end{tabular}

Sebagian besar responden memiliki interaksi sosial sedang yaitu sebanyak 137 responden $(86.2 \%)$.

Tabel 4 Hubungan Culture Shock Dengan Interaksi Sosial Pada Mahasiswa Program Studi S1 Ilmu Keperawatan UNRIYO

\begin{tabular}{|c|c|c|c|c|c|c|c|c|}
\hline \multirow{3}{*}{$\begin{array}{l}\text { Culture } \\
\text { Shock }\end{array}$} & \multicolumn{6}{|c|}{ Interaksi Sosial } & \multirow{2}{*}{\multicolumn{2}{|c|}{ Total }} \\
\hline & \multicolumn{2}{|c|}{ Baik } & \multicolumn{2}{|c|}{ Sedang } & \multicolumn{2}{|c|}{ Kurang } & & \\
\hline & $\mathbf{n}$ & $\%$ & $\mathbf{n}$ & $\%$ & $\mathbf{n}$ & $\%$ & $\mathbf{n}$ & $\%$ \\
\hline $\mathrm{Ya}$ & 10 & 21.3 & 35 & 74.5 & 2 & 4.2 & 47 & 100 \\
\hline Tidak & 8 & 7.1 & 102 & 91.1 & 2 & 1.8 & 112 & 100 \\
\hline Total & 18 & 11.3 & 137 & 86.2 & 4 & 2.5 & 159 & 100 \\
\hline \multicolumn{9}{|c|}{ Uji korelasi $\mathrm{p}=0.075, \mathrm{r}=0.346$} \\
\hline
\end{tabular}

Sebagian besar yang tidak mengalami culture shock menunjukkan interaksi sosial sedang yaitu 102 responden (91.1\%).

Hasi uji Spearman rank $\mathrm{p}=0.075$ $(\alpha<0.05)$ dan $\mathrm{r}=0.346$, berarti tidak ada hubungan yang bermakna antara culture shock dengan interaksi sosial pada responden.

\section{PEMBAHASAN}

\section{Culture Shock Responden}

Hasil dari penelitian menunjukkan mayoritas responden pada penelitian ini tidak mengalami culture shock yaitu sebanyak 112 responden (70.4\%). Hal ini dapat menunjukkan bahwa responden dapat menyesuaikan diri dan beradaptasi dengan lingkungan sekitar. Mahasiswa tingkat pertama dalam berbagai perubahannya akan mengalami reaksi penyesuaian diri, antara lain: kecemasan, kegelisahan, dan depresi yang wajar dialami oleh mahasiswa baru. Responden yang tidak mengalami culture shock dipengaruhi oleh waktu pengambilan data yaitu tidak pada waktu mahasiswa baru datang ke Yogyakarta melainkan pada waktu berada di Yogyakarta selama 10 bulan. Pada umumnya culture shock dialami oleh pendatang selama enam bulan sampai satu tahun pertama kedatangannya. Setelah waktu tersebut menunjukkan seseorang telah mampu beradaptasi dengan lingkungan barunya, meskipun ada perbedaan lama waktu antara orang satu dengan orang yang lain. ${ }^{8}$

Judul penelitian yang hampir sama yaitu Faktor-Faktor Yang Mempengaruhi Culture Shock Pada Mahasiswa Baru PSIK UGM Angkatan 2008 menunjukkan hasil sebagian besar tidak mengalami culture shock yaitu 94 responden $(92.2 \%)$ dan mengalami culture shock yaitu 8 responden (7.8\%). Namun pada judul Culture Shock Pada Mahasiswa Luar Jawa Di Universitas Muhammadiyah Surakarta Ditinjau Dari Etnis Dan Dukungan Sosial, menunjukkan perbedaan hasil yaitu sebagian besar responden mengalami culture shock dalam kategori sedang yaitu sebanyak 36 responden $(60 \%)$.

Berdasarkan hasil, 47 responden (29.6\%) mengalami culture shock. Culture shock mengacu pada tuntutan penyesuaian yang dialami responden pada level fisiologis, kognitif, perilaku, emosi, dan sosial, ketika berpindah ke kebudayaan lain (Yogyakarta). Hal itu dipicu oleh kecemasan individu karena kehilangan simbol-simbol yang selama ini dikenalnya dalam berinteraksi, terutama terjadi saat individu tinggal dalam budaya baru dalam jangka waktu yang relatif lama. ${ }^{9}$

Culture shock berkaitan dengan proses adaptasi seseorang yang melakukan migrasi. Hal ini dapat dilihat dari hasil tabulasi silang yang menyatakan bahwa sebanyak 32 responden $(68.1 \%)$ yang berasal dari NTT mengalami culture shock. Culture shock dialami oleh sebagian orang ketika pergi jauh atau berpindah ketatanan sosial dan budaya yang baru dengan gejala kecemasan dan depresi. ${ }^{10}$ Proses akulturasi merupakan hal penting dalam migrasi seseorang yang selanjutnya terjadi pertemuan lintas budaya 
dan benturan-benturan budaya diantara pendatang dan orang dikebudayaan yang baru.

\section{Interaksi Sosial Responden}

Hasil dari penelitian menunjukkan mayoritas responden pada penelitian ini memiliki interaksi sosial sedang yaitu 137 responden $(86.2 \%)$. Hal ini menunjukkan bahwa responden dapat beradaptasi dengan cukup baik dan mampu menciptakan situasi sosial yang baik dan mampu menciptakan sistem komunikasi efektif. Hal ini karena waktu pengambilan data, mahasiswa sudah berada di Yogyakarta selama 10 bulan. Program OPIEK pada mahasiswa baru juga telah menunjukkan bahwa mahasiswa baru dituntut untuk dapat bersosialisasi dan berinteraksi dengan mahasiswa lainnya. Situasi sosial dapat terjadi jika terdapat saling hubungan antara manusia satu dengan manusia lainnya. ${ }^{11}$ Situasi sosial dapat terjadi melalui 2 tahap yaitu situasi kebersamaan dan situasi kelompok sosial. Situasi kebersamaan biasanya terjadi secara kebetulan karena mereka berada dalam satu tempat dan mempunyai kepentingan yang sama, sedangkan situasi kelompok sosial terjadi akibat adanya tujuan dan kepentingan bersama, sehingga pada keadaan ini kelompok sudah mengadakan interaksi dan hubungan yang lebih mendalam.

Kemampuan interaksi sosial mahasiswa tingkat satu yang termasuk dalam kategori sedang juga disebabkan karena mahasiswa tingkat satu telah melakukan aspek komunikasi, kontak sosial, asimilasi, kerjasama, akomodasi dan kontravensi dengan baik dan melakukan persaingan dan penyelesaian konflik yang cukup ketika berinteraksi dengan orang lain. Syarat terjadinya interaksi sosial adalah adanya komunikasi dan kontak sosial. ${ }^{12}$ Variasi dalam interaksi sosial justru akan menciptakan banyak keuntungan dalam situasi sosial. ${ }^{13}$ Keuntungan yang didapatkan adalah: 1) timbulnya kesadaran adanya kepentingan bersama; 2) koordinasi berbagai kepribadian yang berbeda; 3) memungkinkan terjadinya kerjasama antar kelompok sosial; 4) menghasilkan pola baru dalam penyelesaian masalah; 5) meningkatkan kepribadian dan solidaritas kelompok.

Hasil penelitian yang sama adengan judul Hubungan Keterbukaan Diri Dengan Interaksi Sosial Remaja Di SMA Negeri 5
Surakarta, menunjukkan bahwa sebagian besar responden memiliki interaksi sosial sedang yaitu 45 responden (59.21\%), interaksi sosial baik yaitu 31 responden $(40.79 \%)$ dan tidak ada yang memiliki interaksi sosial yang buruk.

\section{Hubungan Culture Shock Dengan Interaksi Sosial Responden}

Analisis terhadap hubungan culture shock dengan interaksi sosial menunjukkan koefisien korelasi nilai $\mathrm{p}=0.075$ dengan nilai $\mathrm{r}=0.346$. Hal ini berarti tidak ada hubungan yang bermakna antara culture shock dengan interaksi sosial pada responden.

Hasil tersebut sama dengan penelitian yang berjudul Hubungan yang bermakna antara dukungan sosial dengan culture shock pada mahasiswa luar Jawa di Universitas Muhammadiyah Surakarta dengan nilai $p=0.533$ dan $r=-0,082$ dengan perbedaan parameter untuk culture shock yaitu kategori sangat rendah, rendah, sedang, tinggi, sangat tingi dengan skala ordinal.

Culture shock dapat terjadi karena adanya kesulitan dalam beradaptasi dengan lingkungan yang baru serta ketidakmampuan dalam mengatasi kendala-kendala komunikasi dan kendala-kendala budaya. ${ }^{14}$ Kesulitan dalam beradaptasi dengan lingkungan yang baru ini sering tampak dari rasa kehilangan, kerinduan terhadap keluarga dan teman-teman lama. Penelitian ini dilakukan saat responden sudah menjalani pendidikan selama 10 bulan. Hal ini berarti responden sudah memiliki waktu yang lama untuk beradaptasi dan berinteraksi dengan lingkungannya yang sekarang mereka tempati.

Hasil analisis antara culture shock dengan interaksi sosial didapatkan bahwa responden yang tidak mengalami culture shock yaitu $47(29,6 \%)$ responden, sedangkan interaksi sosial dalam kategori kurang hanya yaitu $4(2,5 \%)$ responden. Hal ini menunjukkan bahwa tidak ada keseimbangan antara culture shock dengan interaksi sosial. Jika culture shock mempengaruhi kepribadian seseorang, maka interaksi sosial individu akan terhambat. Ketika seseorang berpergian atau pindah ketatanan sosial dan budaya baru dapat mengalami kecemasan dan depresi yang merupakan manifestasi dari culture shock. ${ }^{7}$ Kesulitan dalam berinteraksi dialami seseorang dapat disebabkan oleh culture shock. 
Hal ini dapat dijelaskan bahwa culture shock tidak mempengaruhi interaksi sosial responden dan dimungkinkan ada faktorfaktor lain yang mempengaruhi interaksi sosial selain culture shock. Perbedaan beberapa faktor yang mendasari interaksi sosial diantaranya adalah imitasi, sugesti, identifikasi dan simpati. ${ }^{15}$ Faktor-faktor tersebut merupakan faktor yang mempengaruhi interaksi sosial atau variabel pengganggu. Hasil penelitian ini, variabel penggangu lebih dominan dibandingkan culture shock. Sehingga tidak ditemukan hubungan yang signifikan antara culture shock dengan interaksi sosial pada responden.

\section{SIMPULAN}

Responden sebagian besar tidak mengalami culture shock. Interaksi sosial responden sebagian besar dalam kategori sedang dan tidak terdapat hubungan bermakna antara culture shock dengan interaksi sosial responden.

\section{SARAN}

Bagi peneliti yang tertarik untuk melakukan penelitian serupa perlu mengkaji lebih dalam mengenai culture shock dengan menggunakan metode kualitatif sehingga dapat diperoleh gambaran yang lebih mendalam mengenai culture shock pada mahasiswa yang berasal dari luar daerah.

\section{KEPUSTAKAAN}

1. Amelia, D. 2008. Culture Shock dan Perilaku Koping pada Mahasiswa Asing (Skripsi). Surakarta: Fakultas Psikologi Universitas Muhammadiyah. Tidak dipublikasikan

2. Setiadi, E. M. \& Hakam, K. A. \& Effendi, R. 2010. Ilmu Sosial \& Budaya Dasar. Kencana Pranada Media Grup

3. Lubis, L. A. 2002. Penerapan Komunikasi Lintas Budaya diantara Perbedaan Kebudayaan [serial online] disitasi pada tanggal 6 Januari 2011]. Diakses dari URL: http://library.usu.ac.id/download/fisip/ko munikasi-lusiana.pdf

4. Potter, P. A. \& Perry, A. G. 2005. Fundamental Keperawatan: Konsep, Proses, dan Praktik, Ed.4. Jakarta: EGC.
5. Xia, J. 2009. Analysis of Impact of Culture Shock on Individual Psychology. International Journal of Psychological studies 9 (2). [serial online] [disitasi pada tanggal 6 Januari 2011]. Diakses dari URL: http://www.ebscohost.com.

6. Irwin, R. 2007. Culture shock: Negotiation Feelings in The Field. Anthropology Matter Journal 9 (1) [serial online] [disitasi pada tanggal 15 Januari 2011]. Diakses dari URL:http://www. anthropologymatters.com

7. Novianti, D. 2009. Faktor-Faktor yang Mempengaruhi Culture Shock pada Mahasiswa Baru Angkatan 2008 PSIK FK UGM (Skripsi). Yogyakarta: Fakultas Kedokteran UGM

8. Austin, Z. 2007. Geographical migration, psychological adjustment, and reformation of professional identity: the doubleculture shock experience of international pharmacy graduates in Ontario (Canada). The Journal of Psicology, 5 (2): 239-255.[serial online] [disitasi pada tanggal 6 Januari 2011]. Diakses dari URL: http://www.ebscohost.com.

9. Siwi, F. R. 2009. Culture Shock Pada Mahasiswa Luar Jawa Di Universitas Muhammadiyah Surakarta Ditinjau Dari Etnis Dan Dukungan Sosial (Skripsi). Surakarta: Fakultas Psikologi Universitas Muhammadiyah. Tidak dipublikasikan

10. Damayanti, M. 2008. Komunikasi Terapeutik Dalam Praktik Keperawatan. Bandung: PT. Refika Aditama

11. Soekanto, S. 2010. Sosiologi suatu pengantar edisi 4. Jakarta : PT Raja gravindo Persada

12. Marfuah, D. 2010. Hubungan Keterbukaan Diri Dengan Interaksi Sosial Remaja Di SMA Negeri 5 Surakarta (Skripsi). Yogyakarta: Fakultas Kedokteran UGM

13. Mulyana, D. 2005. Komunikasi Efektif, Suatu Pendekatan Lintas Budaya. Bandung: PT Remaja Rosdakarya

14. Venes, D. 2005. Culture. Taber's Cyclopedic Medical Dictionary, 20th ed, F.A.

15. Walgito, B. 2003. Psikologi Sosial Suatu Pengantar. Penerbit Andi 